\title{
Social Media Presence and Organizational Performance: An Empirical Study on Companies' Presence on Twitter
}

\author{
Nivo Ravaonorohanta \\ University of Sherbrooke \\ E-Mail: Nivo.Ravaonorohanta@USherbrooke.ca \\ Michel Sayumwe \\ University of Quebec at Montreal \\ E-Mail: sayumwe.michel@uqam.ca
}

\begin{abstract}
Social media has garnered increased attention amongst individuals and organizations. At organizational levels, social media gives companies a way to connect with the market in a real-time manner. It becomes an essential component of marketing and business. However, the economic advantage of the presence of companies on social media platforms remains hardly studied. In this research, we focus on the economic relevance of being on social media, and more specifically on Twitter, at firm levels. With a sample of 227 Canadian companies listed on the Toronto Stock Exchange (TSX), we analyze the relationship between corporate performance and the company's presence on Twitter. Our results suggest that companies can realize a competitive advantage in having social media presence. Indeed, companies that are active on Twitter stand out for their performance; either we measure corporate performance by stock market performance or by return on assets (ROA). Our results highlight the benefits of being active on social media.
\end{abstract}

Keywords: Social media, Presence on Twitter, Tweets, Financial performance, Operating performance, Governance mechanism, Transparency, Legitimacy

\section{INTRODUCTION}

Social media is transforming the way corporations do business and ushering in a new era of communication. The emergence of social media platforms, Facebook, Twitter, LinkedIn, YouTube, and Instagram, to name a few, has brought about a 
profound change in the way companies interact with their stakeholders. These platforms create possibilities for concrete and authentic social interaction through real-time dialogues with users from around the world (Albarrak, Elnahass, Papagiannidis, \& Salama, 2020; Balasubramanian, Fang, \& Yang, 2020; She \& Michelon, 2019).

Social media platforms are distinguished by the ease with which users can share, receive, send messages, and call for comments. Companies run blogs there, start and follow conversations, and broadcast visual and audiovisual content in engaging and fascinating formats. We are concerned with the economic impact of the use of social media by Canadian companies. Do they benefit from maintaining an active presence on social media, and specifically on Twitter? We are particularly interested in the Twitter platform due to its widespread use in the business world. According to Barnes, Lescault, and Wright (2013), 77\% of Fortune 500 companies are active on Twitter. Balasubramanian et al. (2020) find similar patterns for S\&P 500 firms. Besides, it would be unfair not to mention its popularity among celebrities worldwide.

The profile of the use of social media is well documented. Some companies use social media to share information as they do with other non-interactive communication channels (press releases, financial reports, social and environmental reports, etc.) (Alexander \& Gentry, 2014; Hales, Moon, \& Swenson, 2018). Others use it as impression management tools (Bartal, Pliskin, \& Ravid, 2019), to improve their visibility (Yan, Watanabe, Shapiro, Naraine, \& Hull, 2019; Zhang, 2015), or to conduct marketing activities (Menon et al., 2019; Punel \& Ermagun, 2018; Ramsaran-Fowdar $\&$ Fowdar, 2013).

These studies show how social media have changed the way companies work, share information, and connect with customers, shareholders, and all the market. But, while the use of social media has received increasing research attention, few studies have explored the economic advantage of the presence on social media (Gajewski \& Li, 2015; Schniederjans, Cao \& Schniederjans, 2013; Yu, Duan \& Cao, 2013).

Moreover, according to Clement (2019), in her report on Statista that is a portal offering statistics from institutes, surveys, and market research data, Canada had 25.3 million social media users in 2018, and that one-third of them has a Twitter account. These users include individuals, businesses, organizations, and even Parliament. Although social media is now part of everyday life, the use of social media at the corporate level is not widely documented, the economic impact of a presence on social media is even less, hence our interest in the benefits for companies of maintaining an active presence on social media.

Without a clear understanding of its subsequent impact on companies' performance, it is impossible to form an opinion on whether there is a meaningful difference between having and not having social media presence. Drawing on the 
agency theory and the impression management theory, on which most prior research on voluntary disclosure is based (Clark Williams, 2008; Healy \& Palepu, 2001; Merk1Davies \& Brennan, 2011), we analyze the relationship between corporate performance and the company's presence on Twitter.

Our research enriches the literature in several ways. First, we provide a literature review on both the use of social media at organizational levels and its economic relevance. To our knowledge, no consolidated literature review on these topics has been conducted in recent years. Then, we provide empirical evidence on the relationship between corporate performance and the company's presence on Twitter. Besides, we address current issues of voluntary disclosures in the era of social media. Unlike most prior studies that analyze voluntary disclosures on traditional communication channels, we contribute to the literature by examining disclosures on Twitter platforms. Finally, we shed light on the use of Twitter by Canadian companies.

The rest of the paper is structured as follows. First, we review the literature on social media, present the theoretical framework, and develop our research hypothesis. After that, we describe our research methodology. Then, we provide an in-depth analysis of our results. Finally, we draw some general conclusions and discuss possible future research.

\section{USE OF SOCIAL MEDIA IN VOLUNTARY DISCLOSURE}

Research on social media adoption hinges on two major areas: the motivation for voluntary disclosure on social media, and the link between social media use and performance.

Prior research on voluntary disclosure falls into two main categories: incremental information assumption and impression management purpose (Clark Williams, 2008; Healy \& Palepu, 2001; Merkl-Davies \& Brennan, 2011). A stream of literature argues that demand for voluntary disclosure arises from information asymmetry and agency conflicts between managers and investors (Clark Williams, 2008; Healy \& Palepu, 2001). Social media is seen as a voluntary disclosure channel that adds to what companies already use. In their research, Alexander and Gentry (2014), for example, point out that the trend is observed for financial reporting. Disclosure on social media makes it possible for the market to obtain relevant information on a timely basis. This trend is mostly explained by new directives by the SEC (Security Commission Exchange) authorizing the communication of key financial information through social media, as long as the company indicates which one it will use to communicate with its investors.

Financial reporting is just one case among others. The interest of senior business managers on social media dates back long before these guidelines. In his report, Jones 
(2011) mentions the case of the CEO of WebMediaBrands Inc. who seems to see in the Twitter platform a perfect communication channel for all corporate communications. For example, Punel and Ermagun (2018) show in their research for airline companies that social media fits particularly into marketing strategies. As social media engages companies and customers in two-way dialogues, being active on social media allows companies to provide updates, share news, promote their services, and assist clients.

At the same time, it allows companies to get feedback and opinions and identify customer expectations. Chiang, Lo, and Wang (2017), and Chiang, Tu, and Wang (2018) highlight the importance of virtual brand communities in fostering engagement of consumers with the brand and the company. In a similar vein, Menon et al. (2019) find that social media, more specifically Facebook and Twitter, are essential communication channels for building a relationship of trust with consumers and gaining their fidelity.

As such, following the incremental information hypothesis, voluntary disclosure refers to providing more transparency to stakeholders. Adoption of social media would raise efficiency insofar as social media platforms serve as a mechanism for reducing information asymmetry between firms and market participants. Companies would use social media in addition to other traditional communication channels that do not offer the same possibilities in terms of coverage. Because of this high visibility and media coverage, the presence of companies on social media can be interpreted as a commitment to be more transparent.

An alternative view of voluntary disclosure is that managers use reporting discretion to manage public impressions, thus, for an opportunistic perspective. Impression management theory was first introduced by Goffman in 1959 in his seminal work, The Presentation of Self in Everyday Life, and further worked out, deepened and anchored in numerous studies including Prakash and Rappaport (1977), Schlenker (1980), Leary and Kowalski (1990), and Merkl-Davies and Brennan (2011).

Drawing on Goffman (1959), among others, Parhankangas \& Ehrlich (2014, p.545) define impression management as "A process through which people seek to influence the image others have of them in order to attain a specific goal". Bolino, Kacmar, Turnley, and Gilstrap (2008) further argue that impression management can be achieved by either concealing negative outcomes or emphasizing positive outcomes. Described in this way, impression management may be viewed at a firm-level as a deliberate strategy to manipulate perceptions by putting the best part of the company into stakeholders.

The voluntary nature of the disclosure on the Twitter platform makes it a powerful tool for impression management. Indeed, using social media allows companies to bring information whenever they wish, select the information to display, and present the 
information in the form they want. In that way, social media offers an excellent opportunity to positively shape perceptions of stakeholders towards the company and hence manage corporate image and legitimacy (Cade, 2018; Gruber, Smerek, ThomasHunt, \& James, 2015; She \& Michelon, 2019).

The use of social media to spread, share, and highlight the company's commitment to a social cause, even if it is only an appearance, is one example. She and Michelon (2019) focus on publications related to social and environmental responsibility, but the strategy extends to all spheres of public life, such as the fight against cancer, autism, or climate change. The high social media coverage of the company's commitment to a cause that affects the Society's sensitive cords creates positive public reaction towards the maintenance of legitimacy while mitigating negative perceptions.

Social media is considered to be one of the powerful tools to manage crises that challenge reputation and legitimacy. The results obtained by Gruber et al. (2015) support this view. The risk that social media would amplify crises is real, but their results show that managers can exploit the attributes of social media to resolve them by making themselves heard, acting within an optimal timeframe, and interacting with the public in real-time. The results obtained by Cade (2018) in an experiment with investors go in the same direction. Social media provide an opportunity for managers to participate actively in conversations while staying in control and to redirect participants' attention to positive points.

Following these studies, using social media helps companies to maintain an appearance of acting in a way that is consistent with social norms, reduce the gap between informed and uninformed investors, and to be rewarded with positive investors' reaction. Table 1 summarizes the research on the theoretical motivations for the adoption of social media by companies we discussed. 
Table 1. The Theoretical Motivations for the Adoption of Social Media by Companies

\begin{tabular}{|c|c|c|}
\hline Motivations & Authors & Disclosure purposes \\
\hline \multirow{3}{*}{ Transparency } & $\begin{array}{l}\text { Alexander and Gentry } \\
(2014)\end{array}$ & - To report financial results \\
\hline & Punel and Ermagun (2018) & $\begin{array}{l}\text { - To share updated content in a timely } \\
\text { manner } \\
\text { - To provide customer service } \\
\text { - To detect new market segments }\end{array}$ \\
\hline & $\begin{array}{l}\text { Menon et al. (2019) } \\
\text { Chiang, Lo and Wang } \\
\text { (2017) } \\
\text { Chiang, Tu and Wang } \\
\text { (2018) }\end{array}$ & $\begin{array}{l}\text { - To have interactive exchanges of } \\
\text { opinions } \\
\text { - To build a relationship of trust } \\
\text { - To build brands' image }\end{array}$ \\
\hline \multirow{3}{*}{$\begin{array}{l}\text { Impression } \\
\text { Management }\end{array}$} & She and Michelon (2019) & $\begin{array}{l}\text { - To manage stakeholders' } \\
\text { perceptions with CSR hypocrisy } \\
\text { disclosure }\end{array}$ \\
\hline & $\begin{array}{l}\text { Gruber, Smerek, Thomas- } \\
\text { Hunt, and James (2015) }\end{array}$ & $\begin{array}{l}\text { - To highlight actions in crisis } \\
\text { management }\end{array}$ \\
\hline & Cade (2018) & $\begin{array}{l}\text { - To manage investors' perceptions of } \\
\text { legitimacy-threatening events }\end{array}$ \\
\hline
\end{tabular}

Another stream of research focuses on the outcomes of the adoption of social media in terms of performance at organizational levels. The outcome of being on social media remains less studied compared to the motivation for the use of social media itself. Nevertheless, the few studies carried out in four countries (France, Spain, Turkey, the USA) tend to show a positive link between the presence of the company on social media and its performance.

Within a sample of 902 observations on 25 Spanish firms belonging to IBEX, Paniagua and Sapena (2014) show that the presence of companies on social media is associated with an improvement in their financial performance, even while the initial investment cost to maintain and increase the presence on social media can be high. This cost includes creating content, hiring platform managers, hiring and training people who speak on behalf of the company, and who will interact with followers in real-time. Moreover, their results show that Twitter is more powerful than Facebook to enhance firms' performance.

$\mathrm{Ng}$ (2013) obtains similar results with a sample of social media users case studies, involving 108 successful cases and 18 failed cases obtained from the trade press. 
According to his findings, the presence of the companies on social media would mitigate the negative reaction of the market to the announcement of unfavorable news by the companies. We have seen above that companies use social media to communicate relevant information in a timely manner. His results support this idea and show that the market rewards the proximity generated by the active presence of the company on social media. It follows a certain attachment to the company that tips the balance in its favor when it comes to the investors' decisions.

The results obtained by Gajewski and Li (2015) go in the same direction. With a sample of 180 French firms belonging to the SBF 250 index, they show that an active presence of companies on social media reduces the asymmetry of information between the company and the market. The negative link between the presence of companies on social media and the bid-ask spread corroborates the reduction in the asymmetry of information. Albarrak et al. (2020) find similar evidence with observations from 791 non-financial firms listed on the US NASDAQ. Their results show that using social media help reduce information asymmetry between investors and a firm, and thereby significantly reduces the cost of equity.

Prior research also shows that an active presence on social media is associated with low risks of insider trading, suggesting an improvement in the corporate information environment. Yu et al. (2013) analyze the relative importance of social media compared to traditional media and their interaction on business performance with a sample of 824 companies from Compustat and the Center of Research in Security Prices (CRSP) databases. Their results suggest that social media is more relevant compared to conventional media. These show that social media and conventional media interact on the company's stock market performance, but that the correlation between performance and social media is higher compared to the performance of the other media.

The results of Schniederjans et al. (2013) are more nuanced than the previous ones. Adopting the theoretical approach of impression management, they show that social media is an effective vehicle that companies use to implement assertive impression management strategies such as ingratiation, intimidation, organizational promotion, exemplification, and supplication to shape stakeholders' perceptions. Their results show that such disclosures attract positive reactions from stakeholders, and thereby affect financial performance positively, but their effectiveness would largely depend on the impression management tactic. Nonetheless, their results do not call into question the power of social media to shape investors' perceptions positively.

We summarize in Table 2 the literature on the link between the presence of companies on social media and the performance that we discussed. 
Table 2. Presence on Social Media and Performance

\begin{tabular}{lcl}
\hline \multicolumn{1}{c}{ Authors } & \multicolumn{1}{c}{ Outcomes of social media presence } \\
\hline Paniagua and Sapena (2014) & - $\begin{array}{l}\text { Positive links between social media presence (Twitter } \\
\text { and/or Facebook) (Followers, Likes) and share value }\end{array}$ \\
\hline Ng (2013) & - $\begin{array}{l}\text { Positive effects on sales, revenue, return on } \\
\text { investment, market expansion }\end{array}$ \\
& Negative effects on advertising costs \\
\hline Gajewski and Li (2015) & - $\begin{array}{l}\text { Low information asymmetry that is measured by } \\
\text { spread and the probability of informed trading }\end{array}$ \\
\hline $\begin{array}{l}\text { Albarrak, Elnahass, } \\
\text { Papagiannidis, and Salama } \\
\text { (2020) }\end{array}$ & Reduced cost of equity (equity premium) \\
\hline Yu, Duan, and Cao (2013) & - $\begin{array}{l}\text { A stronger relationship between social media and firm } \\
\text { stock performance (return and risk) than for } \\
\text { conventional media. }\end{array}$ \\
\hline $\begin{array}{l}\text { Schniederjans, Cao, and } \\
\text { Schniederjans (2013) }\end{array}$ & $\begin{array}{l}\text { A positive effect of social media's usage on financial } \\
\text { performance for some assertive impression } \\
\text { management strategies }\end{array}$ \\
\hline
\end{tabular}

Overall, research shows that the presence of companies on social media, whether for economic motives (to promote transparency) or for opportunistic motives (to manage impressions) is rewarded by the market. Companies gain social legitimacy that reflects through its profitability and performance. From an economic perspective, companies are rewarded for the signal of organizational openness and transparency they send through voluntary disclosures. From an opportunistic perspective, investors are assumed unable to assess that managerial posts on social media present an inaccurate view of organizational outcomes, and react favorably to such disclosures as they do for incremental information.

Based on the above, we argue that having a presence on the Twitter platform drives superior firm performance. However, companies would not achieve the expected result without an active presence in a timely manner that is evidenced by the number of tweets and the number of followers. Accordingly, we hypothesize that:

Hypothesis: An active presence of companies on Twitter is associated with better corporate performance.

In this study, we focus on operating performance and financial performance. 


\section{METHODOLOGY AND DATA SOURCES}

The main objective of this research is to provide empirical evidence of the link between the presence on social media, particularly on the Twitter platform, and corporate performance.

\section{Sample Selection}

The population from which our sample is selected comprises all the Canadian listed companies on the Toronto Stock Exchange (TSX) in 2017. Table 3 presents a detailed breakdown of the sample selection process that we use in our research.

\section{Table 3. Sample Selection}

\begin{tabular}{lrr}
\hline \multicolumn{1}{c}{ Sample criteria } & Excluded & Sample size \\
\hline Canadian companies on TSX on December 31,2017 & - & 1515 \\
Market capitalization below 1 billion Canadian dollars & 1258 & 257 \\
Without necessary Compustat, Capital IQ or Bloomberg data & 25 & 232 \\
Twitter account has no public access & 5 & 227 \\
\hline
\end{tabular}

As of December 31, 2017, there were 1,515 companies registered. We limit our sample to companies with a market capitalization of at least 1 billion Canadian dollars, which may be more likely to adopt new technology early. In this way, we increase the probability of capturing companies that use Twitter in our research. Of the remaining 257 medium to large market capitalization companies, we removed those for which financial information, information on governance were not available on Compustat, Capital IQ, or on Bloomberg databases, leaving a sample of 232 companies. We then removed companies where we could not get sufficient data about the presence on the Twitter platform, mainly because their Twitter accounts have no public access. These elimination criteria led to a final sample of 227 companies.

Table 4 presents the distribution of the companies in our sample according to their industry sector. The industrial, mining, and energy sectors account for more than half of the sample $(55.95 \%)$, followed by the financial services $(12.33 \%)$ and real estate $(8.81 \%)$. This distribution is representative of that of all the companies active on the TSX market. Among these companies, $60.8 \%$ have an official Twitter account. 
Table 4. Sample Composition by Industry Sector

\begin{tabular}{lcc}
\hline Industry Sectors & Number & Percentage \\
\hline Diversified Industries & 59 & 25.99 \\
Mines & 36 & 15.86 \\
Oil and gas & 32 & 14.10 \\
Financial services & 28 & 12.33 \\
Real Estates & 20 & 8.81 \\
Public services, utilities, and pipelines & 33 & 14.54 \\
Communications and media & 9 & 3.96 \\
Forest products and paper & 7 & 3.08 \\
Life sciences & 3 & 1.32 \\
\hline Total & $\mathbf{2 2 7}$ & $\mathbf{1 0 0 . 0 0}$ \\
\hline
\end{tabular}

\section{Presence on Social Media and Performance}

We advance the hypothesis that the active presence of companies on Twitter is associated with better corporate performance. To test our hypothesis, we deploy a predictive model based on the characteristics of companies' presence on Twitter. In addition to the main variables of interest, we include a set of control variables from prior research.

Our multiple linear regression model specified as follows:

$$
\begin{aligned}
\text { Performance }= & \delta_{0}+\delta_{1} \text { On Twitter }+\delta_{2} \text { Followers }+\delta_{3} \text { Tweet }+\delta_{4} \text { Market Capitalization } \\
& +\delta_{5} \text { Leverage }+\delta_{6} \text { Board Size }+\delta_{7} \text { Independence }+\delta_{8} \text { Meeting }+\delta_{9} \\
& \text { Attendance }+\delta_{10} \text { Governance Index }+\varepsilon
\end{aligned}
$$

Concerning the corporate performance, several measures are proposed in the literature, including the stock market and accounting measures (Du \& Jiang, 2015; Hales et al., 2018; Ng, 2013; Paniagua \& Sapena, 2014). Our dependent variable is then measured in two ways, first according to the return on assets (ROA) for the year 2017, then according to the average of the daily financial returns for the year 2017.

The main variables of interest in our research relate to the active presence of companies on the Twitter platform. Following Paniagua and Sapena (2014), and Balasubramanian et al. (2020), we assess the presence of the company on the Twitter platform in three ways: the existence of an official account in the name of the company, the number of tweets, and the number of followers. Twitter presence denotes that the company has an official main account on the Twitter platform. The number of followers is the number of users who follow the company on the Twitter platform. According to Clark and Melancon (2013), the number of followers indicates how well the company 
is connected with its stakeholders, whereas the number of tweets conveys its openness and transparency.

We searched each company in our sample on the Twitter platform to retrieve data about its presence on it. In this research, a company is considered present on the Twitter platform if it had an official main account before January 2017. We then captured the content of each Twitter page with NVivo to record the number of tweets, the number of followers, and the year that the company established its Twitter main account. For some companies, it was impossible to import relevant information on their social media presence into NVivo. We then manually collect data information for these companies.

In our regression model, On Twitter is a dummy variable that equals one if the company has had an official Twitter account before January 2017. Tweet is the average number of tweets made by the company between the time it joined Twitter and the end of 2017. All other variables are measured at the end of 2017. Followers is the number of individuals and companies that connect with the company and receive their tweets. It should be noted that the number of tweets we consider in this research does not include retweets.

Following prior research, we consider a set of control variables that are likely to influence the company's communication strategy and performance, including company size, leverage, and governance characteristics. Gajewski and Li (2015), and Benthaus, Risius, and Beck (2016) show that the company's communication strategies would depend on its size. Indeed, large companies do not have the same communication needs nor the same communication costs as medium companies. Following Modigliani and Miller (1958), and Campello (2006), as a primary financial risk indicator, higher leverage induces financial uncertainty. Thus, companies that use more financial leverage are more likely to have high default risk and underperform. In the regression model, we use the market capitalization to measure the company size. Leverage is total debt divided by total equity of the company.

Numerous studies suggest that better governance increases the value of the company by preventing wealth distribution for the benefit of managers, but to the detriment of shareholders. The independence and size of the board of directors are frequently used in research to measure the effectiveness of corporate governance (García-Sánchez, Hussain \& Martínez-Ferrero, 2019; Withers, Hillman \& Cannella, 2012). We use corporate governance variables that are traditionally used in previous studies; however, we introduce other measures found in some research. Whereas common measures of corporate governance deal with the overall structure of boards of directors, new measures focus on its operating methods, and thus the way board members participate in decision-making and perform their monitoring and advisory roles. These are board meeting frequency, board meeting attendance, and governance 
index designed by Bloomberg (Adams \& Ferreira, 2009; Masulis, Wang, \& Xie, 2012; Stein \& Zhao, 2019; Vafeas, 1999).

In our model, Board Size is the number of directors serving on the corporate board. Board independence is the proportion of directors who are not corporate executives. Meeting is the annual board meeting frequency. Attendance is the board members' attendance record at board meetings. Governance Index is the score of a company's environmental, social, and governance quality, as given by Bloomberg. The study variables, the measures, and the data sources are summarized in Table 5.

Table 5. Study Variables

\begin{tabular}{|c|c|c|c|}
\hline Variables & Authors & Measure & Data Sources \\
\hline Performance & Yu et al. (2013) & $\begin{array}{l}\text { - Average daily market } \\
\text { return } \\
\text { - } \text { ROA in } 2017 \\
\end{array}$ & $\begin{array}{l}\text { Compustat } \\
\text { TSX }\end{array}$ \\
\hline $\begin{array}{l}\text { Presence on } \\
\text { Twitter }\end{array}$ & $\begin{array}{l}\text { Paniagua and Sapena } \\
(2014) \\
\text { Akmese, Aras, and } \\
\text { Akmese (2016) }\end{array}$ & $\begin{array}{l}\text { - } \text { Twitter account }(1 / 0) \\
\text { - Number of followers } \\
\text { - Average annual number of } \\
\text { tweets }\end{array}$ & $\begin{array}{l}\text { Twitter } \\
\text { Account }\end{array}$ \\
\hline Leverage & $\begin{array}{l}\text { Du and Jiang (2015), } \\
\text { Balasubramanian, Fang, } \\
\text { and Yang (2020) }\end{array}$ & $\begin{array}{l}\text { - Debt divided by total } \\
\text { equity }\end{array}$ & $\begin{array}{l}\text { Capital IQ. } \\
\text { Compustat }\end{array}$ \\
\hline $\begin{array}{l}\text { Corporate } \\
\text { Size }\end{array}$ & $\begin{array}{l}\text { Yu, Duan, and Cao } \\
\text { (2013); Benthaus et al. } \\
(2016)\end{array}$ & - Market Capitalization & $\begin{array}{l}\text { Capital IQ. } \\
\text { Compustat }\end{array}$ \\
\hline Governance & $\begin{array}{l}\text { Masulis et al. (2012) } \\
\text { Stein and Zhao (2019) }\end{array}$ & $\begin{array}{l}\text { Board size, independence } \\
\text { of the board, meeting } \\
\text { frequency, and attendance } \\
\text { governance index }\end{array}$ & $\begin{array}{l}\text { Capital IQ, } \\
\text { Compustat } \\
\text { Bloomberg }\end{array}$ \\
\hline
\end{tabular}

\section{RESULTS}

This section presents the empirical effects of the companies' presence on the Twitter platform on its operating and financial performance. The descriptive statistics for the study variables are shown in Table 6 . 
Table 6. Descriptive Statistics for Study Variables (sample size = 227)

\begin{tabular}{lrrrrr}
\hline \multicolumn{1}{c}{ Variables } & \multicolumn{1}{c}{ Mean } & Median & Std. Dev. & Minimum & Maximum \\
\hline On Twitter $\left.{ }^{*}\right)$ & 0.608 & 1.000 & 0.489 & 0.000 & 1.000 \\
Tweet & 1136.480 & 17.400 & 5186.222 & 0.000 & 60447.400 \\
Followers & 14697.577 & 264.000 & 59633.459 & 0.000 & 671226.000 \\
ROA & 3.861 & 3.616 & 6.829 & -39.963 & 35.182 \\
Board Size & 9.714 & 9.000 & 2.623 & 5.000 & 18.000 \\
Board Independence & 78.244 & 80.000 & 12.569 & 7.000 & 94.118 \\
Leverage & 26.619 & 25.032 & 15.805 & 0.346 & 87.808 \\
Meeting & 8.789 & 8.000 & 4.591 & 4.000 & 52.000 \\
Attendance & 97.743 & 98.570 & 3.292 & 75.000 & 100.000 \\
Governance Index & 54.869 & 51.786 & 7.269 & 39.286 & 78.571 \\
Market Capitalization & 9.744 & 3.123 & 17.813 & 1.001 & 135.600 \\
Daily Market Return & -0.183 & -0.146 & 0.950 & -4.966 & 2.647 \\
\hline
\end{tabular}

${ }_{(*)}$ The mean represents the proportion of firm with value equals to 1

According to Table 6, 60.8\% of companies within our sample have a Twitter account, corresponding to 138 out of 227 companies. On average, each company has 14,697 followers and posts 1,136 tweets per year or three tweets per day. These results are comparable to those reported by Gomez-Carrasco and Michelon (2017) when assessing the influence of social media activism on stock market performance. The average daily return is $-0.183 \%$ while the minimum is $-4.9 \%$, and the maximum is $2.6 \%$. The mean operating performance (ROA) is positive $(3.861 \%)$, the median is $3.616 \%$. The mean of market capitalization in our sample is $\$ 9.7$ billion, for a minimum of $\$ 1.0$ billion and a maximum of $\$ 135.6$ billion.

Our sample companies have a mean leverage of $26.6 \%$ for a minimum of $0.35 \%$ and a maximum of $87.8 \%$. Moving onto governance indicators, the average corporate board consists of 9.714 members, of which $78.244 \%$ are independent. This trend is consistent with the evidence presented by Chen, Leung, Song, and Goergen (2019), who show a mean of 9.368 board members, of which $72.6 \%$ are independent. Boards of directors in our sample companies hold a mean of 8.789 meetings per year. The mean of the board meeting attendance rate is $97.743 \%$. These results are comparable to those of Chen, Lai, and Chen (2015), who show that boards of directors hold a mean 8.064 of meetings after the Sarbanes-Oxley Act of 2002.

We start our empirical investigation by conducting univariate comparisons of financial returns and accounting returns between companies with a Twitter account and companies without, to evaluate whether there is a meaningful economic advantage to be on Twitter. 
Table 7. Corporate Performance and Presence on Twitter Platform

\begin{tabular}{lccc}
\hline \multicolumn{1}{c}{ Variables } & On Twitter & Not on Twitter & Sig. \\
\hline Observations & 138 & 89 & \\
Daily Market Return & 0,088 & $-0,603$ & $* * *$ \\
ROA & 4,436 & 2,968 & $*$ \\
\hline$* * *$ significant at $1 \% ; *$ significant at $10 \%$ & &
\end{tabular}

A comparison of average daily market returns shows that companies that are on Twitter outperform those that are not. The averages are respectively $0.088 \%$, and $-0.603 \%(\mathrm{p}<.01)$. We get a similar trend with the return on assets. Companies that are on Twitter get $1.467 \%$ more return $(p<.1)$ than ones that are not on Twitter. These findings indicate the benefits of being on Twitter. We complete the univariate analysis with additional tests based on our predictive model that combines characteristics of the companies' presence on Twitter, characteristics of the companies, and corporate governance variables.

The results of the OLS regressions are shown in Table 8.

Table 8. Links between the Presence of Companies on Twitter and Performance

\begin{tabular}{|c|c|c|c|c|}
\hline Variables & $\begin{array}{c}\text { Model } 1 \\
\text { Daily Market return }\end{array}$ & & $\begin{array}{c}\text { Model } 2 \\
\text { ROA }\end{array}$ & \\
\hline Constant & -1.718 & & 8.884 & \\
\hline Attendance & 0.072 & & 0.102 & \\
\hline Market Capitalization & -0.060 & & -0.003 & \\
\hline Independence & 0.080 & & -0.080 & $* *$ \\
\hline Governance Index & 0.020 & $* *$ & 0.095 & $* * *$ \\
\hline Meeting & -0.023 & $* *$ & -0.117 & \\
\hline Followers & -0.019 & & -0.004 & \\
\hline On Twitter & 0.411 & $* * *$ & 2.137 & $* *$ \\
\hline Board Size & -0.065 & & -0.006 & \\
\hline Leverage & -0.016 & $* * *$ & -0.210 & $*$ \\
\hline Tweet & 0.001 & $* * *$ & -0.004 & \\
\hline $\mathrm{N}$ & 227 & & 227 & \\
\hline Durbin-Watson & 1,8 & & 1,7 & \\
\hline $\mathrm{F}$ & 15.160 & $* * *$ & 13.120 & $* * *$ \\
\hline Adjusted $\mathrm{R}^{2}$ & $23.9 \%$ & & $14.7 \%$ & \\
\hline
\end{tabular}

*** significant at $1 \%$; ** significant at $5 \%$, $*$ significant at $10 \%$

Model 1 explains the firm performance as measured by the daily market return. The model is globally significant and explains $23.9 \%$ of the variation in business 
performance. The Durbin-Watson coefficient is between 1.5 and 2.5, indicating the absence of autocorrelations of the residues. Results support our earlier findings under Table 7. The presence on Twitter is positively correlated with the company's stock market performance. Indeed, all other things being equal, companies on Twitter get $0.411 \%(\mathrm{p}<.01)$ more stock return than ones that are not on Twitter. The number of tweets also is positively correlated to stock market performance. The coefficient seems rather low. However, in terms of economic significance, every 1,000 additional tweets per year, or three additional tweets per day, increases the daily market return of the company by $1 \%$, which is meaningful considering the average daily market return of $0.183 \%$. These results lend support to our hypothesis on the link between the presence of companies on Twitter and corporate performance.

However, the number of followers of the company on Twitter is not statistically significant. This could be interpreted in the sense that it is not the number of natural or legal persons who follow the company that counts, but what matters is the presence as such on social networks that would be perceived as a guarantee of fast and succinct communication of the company that is followed.

When we measure financial performance by operating performance (ROA) (Model 2 ), we notice that the results go in the same direction as according to the stock market return. The presence of companies on Twitter is positively correlated with the return on assets $(\beta=2.137 ; \mathrm{p}<.05)$. However, an in-depth comparison of the two series of models suggests that the measurement of financial performance by stock return is more robust than the measurement by ROA. Indeed, the explanatory power of the stock market return model is $23.9 \%$ while it is $14.7 \%$ for the ROA.

Looking at control variables, the governance index is positively correlated with the daily market return $(\beta=0.020 ; p<.05)$, as well as to the ROA $(\beta=0.095 ; \mathrm{p}<.01)$, suggesting that well-governed companies get better performance. These results are consistent with most studies on governance and corporate performance (Masulis, Wang, \& Xie, 2007; Davila \& Penalva, 2006). We document a negative and significant relationship between the board meeting frequency and the daily market return $(\beta=$ -0.023; $\mathrm{p}<.05)$. Vafeas (1999) gets similar results. Following the author, the increasing board activity results from a share price decline and does not necessarily indicate improved monitoring roles. Our result does not show that board independence leads to better operating performance; the coefficient is significantly negative $(\beta=-0.080 ; \mathrm{p}$ $<$.05). This is consistent with some previous findings (Dutta \& Jog, 2009; Fracassi \& Tate, 2012). The financial leverage is negatively correlated either with the daily market return $(\beta=-0.016 ; \mathrm{p}<.01)$, or the $\operatorname{ROA}(\beta=-0.210 ; \mathrm{p}<.1)$. We thus provide corroborating evidence that high financial leverage leads to high default risk and low performance (Campello, 2006; Modigliani \& Miller, 1958). 
One objective of our study is to examine the use of Twitter platform within Canadian firms. We show that $60.8 \%$ of companies have a Twitter account. This is consistent with the evidence in prior research in other countries (Balasubramanian et al., 2020; Barnes et al., 2013).

Overall, our results show that having an active presence on Twitter significantly enhances corporate performance. Companies with a higher number of tweets outperform their peers with less, or that do not have any Twitter account. Our results confirm and extend prior findings by highlighting the effect of the presence of companies on Twitter platforms in terms of financial performance and operating performance. These results support the two theories we draw from (i.e., agency theory and impression management theory) and show that voluntary disclosure on the Twitter platforms follows the pattern of voluntary disclosure using traditional channels.

From the agency theory perspective, our results suggest that companies are rewarded for incremental information they send through voluntary posts on Twitter. External stakeholder communities seem to see in the number of a company's Tweet a signal of its openness and transparency that significantly enhances its social legitimacy, trustworthiness, and customer loyalty that in turn lead to improved corporate performance. In this way, our results are in line with prior research that suggests social media helps companies to build a relationship of trust with their stakeholders (Chiang et al., 2017; Chiang et al., 2018); and that the market rewards the proximity generated by the active presence of the company on social media (Albarrak et al., 2020; Gajewski $\& \mathrm{Li}, 2015)$.

From the impression management perspective, our findings suggest that companies are rewarded for managerial tweets even though some tweets may present an enhanced and inaccurate view of the company's performance, and are thus designed to manipulate stakeholders' perceptions rather than to improve transparency. As the stakeholders are unable to assess managerial bias, they react favorably to such disclosures as they do for incremental information. Again, our results are consistent with previous findings on the positive impact of opportunistic disclosures on firm performance (Merkl-Davies \& Brennan, 2011; Schniederjans et al., 2013).

\section{CONCLUSION}

This study was motivated by the increasing use of social media platforms at organizational levels. In recent years, social media have opened up new communication channels and changed the way companies work, share information, and connect with customers and shareholders. Our paper provides an empirical examination of the link between the companies' presence on the Twitter platform and its performance. Our study enriches the literature in several ways. We extend the literature on social media 
by highlighting the effect of the presence of companies on Twitter platforms in terms of financial performance and operating performance. We also contribute to the literature on voluntary disclosure on studying a new disclosure medium.

Our results support our hypothesis and show that companies that have an active presence on the Twitter platform stand out for their performance; either we measure corporate performance by stock market performance or by return on assets (ROA), lending support to the agency theory and the impression management theory we draw from.

Our findings suggest that companies can use the Twitter platform to mitigate agency problems. Twitter offers companies great opportunities to connect with all market participants. External stakeholder's communities see in the active presence of companies on the Twitter platform a signal of openness, accessibility, and transparency that accrue to the companies in terms of operating performance and market value. They perceive posts on the Twitter platform as credible, even though some tweets may be opportunistic, and are thus designed to positively shape perceptions.

Companies must realize the power of social media and must adapt their voluntary disclosure strategies to this new reality. Our findings suggest that companies have an interest in integrating social media into their voluntary disclosure strategies. The question is no longer whether or not companies should adhere to social media but rather how to use it as a lever to improve performance. However, to stay in tune, the company must monitor the various communication channels used by its competitors.

Since many companies are present on the Twitter platform, the best way to stand out is to disseminate relevant but succinct information that attracts the curiosity of current and future investors. It is common practice to establish an experienced editorial board to produce successful content for social media posts. Such messages are also addressed to employees, current and potential customers, and generally the community in which the company operates.

One limitation of this research is that it examines the Twitter platform only; future research can consider other types of social media companies use jointly with Twitter such as LinkedIn. As mentioned earlier, by establishing a presence in social media like Twitter, corporations give an illusion of a commitment for better transparency; future research may examine the content of the company's tweets.

\section{REFERENCES}

Adams, R.vB., \& Ferreira, D. (2009). Strong managers, weak boards?. CESifo Economic Studies, 55(3-4), 482-514. https://doi.org/10.1093/cesifo/ifp023

Akmese, H., Aras, S., \& Akmese, K. (2016). Financial performance and social media: A research on tourism enterprises quoted in Istanbul stock exchange (BIST). 
Procedia Economics and Finance, 39, 705-710. https://doi.org/10.1016/ S22125671(16)30281-7

Albarrak, M. S., Elnahass, M., Papagiannidis, S., \& Salama, A. (2020). The effect of twitter dissemination on cost of equity: A big data approach. International Journal of Information Management, 50, 1-16. https://doi.org/10.1016 /j.ijinfomgt.2019.04.014

Alexander, R. M., \& Gentry, J. K. (2014). Using social media to report financial results. Business Horizons, 57(2), 161-167. https://doi.org/10.1016/j.bushor.2013.10.009

Balasubramanian, S. K., Fang, Y., \& Yang, Z. (2020). Twitter presence and experience improve corporate social responsibility outcomes. Journal of Business Ethics. https://doi.org/10.1007/s10551-020-04537-x

Barnes, N. G., Lescault, A. M., \& Wright, S. (2013). Fortune 500 are bullish on social media: Big companies get excited about Google+, Instagram, Foursquare and Pinterest. Journal of New Communications Research, 5(2), 72-77

Bartal, A., Pliskin, N., \& Ravid, G. (2019). Modeling influence on posting engagement in online social networks: Beyond neighborhood effects. Social Networks, 59, 6176. https://doi.org/10.1016/j.socnet.2019.05.005

Benthaus, J., Risius, M., \& Beck, R. (2016). Social media management strategies for organizational impression management and their effect on public perception. The Journal of Strategic Information Systems, 25(2), 127-139. https://doi.org/10.1016 /j.jsis.2015.12.001

Bolino, M. C., Kacmar, K. M., Turnley, W. H., \& Gilstrap, J. B. (2008). A Multi-Level Review of Impression Management Motives and Behaviors. Journal of Management, 34(6), 1080-1109. https://doi.org/10.1177/0149206308324325

Cade, N. L. (2018). Corporate social media: How two-way disclosure channels influence investors. Accounting, Organizations and Society, 68-69, 63-79. https://doi.org/10.1016/j.aos.2018.03.004

Campello, M. (2006). Debt financing: Does it boost or hurt firm performance in product markets?. Journal of Financial Economics, 82(1), 135-172. https://doi.org/ 10.1016/j.jfineco.2005.04.001

Chen, J., Leung, W. S., Song, W., \& Goergen, M. (2019). Why female board representation matters: The role of female directors in reducing male CEO overconfidence. Journal of Empirical Finance, 53, 70-90. https://doi.org/10.1016 /j.jempfin.2019.06.002

Chen, L.-Y., Lai, J.-H., \& Chen, C. R. (2015). Multiple directorships and the performance of mergers \& acquisitions. The North American Journal of Economics and Finance, 33, 178-198. https://doi.org/10.1016/j.najef.2015.04.004 
Chiang, I., Lo, S., \& Wang, L.-H. (2017). Customer engagement behaviour in social media advertising: Antecedents and consequences. Contemporary Management Research, 13(3), 193-216. https://doi.org/10.7903/cmr.17673

Chiang, I., Tu, S., \& Wang, L. (2018). Exploring the social marketing impacts of virtual brand community engagement. Contemporary Management Research, 14(2), 143164. https://doi.org/- 10.7903/cmr.18086

Clark Williams, C. (2008). Toward a taxonomy of corporate reporting strategies. Journal of Business Communication, 45(3), 232-264. https://doi.org/10.1177 $/ 0021943608317520$

Clark, M., \& Melancon, J. (2013). The influence of social media investment on relational outcomes: A relationship marketing perspective. IJMS International Journal of Marketing Studies, 5(4). https://doi.org/10.5539/ijms.v5n4p132

Clement, J. (2019). Social networking in Canada - Statistics \& Facts [statista]. Retrieved from https://www.statista.com/topics/2729/social-networking-incanada/

Davila, A., \& Penalva, F. (2006). Governance structure and the weighting of performance measures in CEO compensation. Review of Accounting Studies, 11(4), 463-493. https://doi.org/10.1007/s11142-006-9018-8

Du, H., \& Jiang, W. (2015). Do social media matter? Initial empirical evidence. Journal of Information Systems, 29(2), 51-70. https://doi.org/10.2308/isys-50995

Dutta, S., \& Jog, V. (2009). The long-term performance of acquiring firms: A reexamination of an anomaly. Journal of Banking and Finance, 33(8), 1400-1412. https://doi.org/10.1016/j.jbankfin.2009.02.004

Fracassi, C., \& Tate, G. (2012). External networking and internal firm governance. The Journal of Finance, 67(1), 153-194. https://doi.org/10.1111/j.1540-6261.2011. 01706.x

Gajewski, J.-F., \& Li, L. (2015). Can internet-based disclosure reduce information asymmetry?. Advances in Accounting, 31(1), 115-124. https://doi.org/10.1016 /j.adiac.2015.03.013

García-Sánchez, I.-M., Hussain, N., \& Martínez-Ferrero, J. (2019). An empirical analysis of the complementarities and substitutions between effects of CEO ability and corporate governance on socially responsible performance. Journal of Cleaner Production, 215, 1288-1300. https://doi.org/10.1016/j.jclepro.2019.01.130

Goffman, E. (1959). The presentation of self in everyday life. Doubleday Anchor Books.

Gomez-Carrasco, P. \& Michelon, G. (2017). The power of stakeholders' voice: The effects of social media activism on stock markets. Business Strategy and the Environment, 26(6), 855-872. https://doi.org/10.1002/bse.1973 
Gruber, D. A., Smerek, R. E., Thomas-Hunt, M. C., \& James, E. H. (2015). The realtime power of Twitter: Crisis management and leadership in an age of social media. Business Horizons, 58(2), 163-172. https://doi.org/10.1016/j.bushor.2014. 10.006

Hales, J., Moon, J. R. \& Swenson, L. A. (2018). A new era of voluntary disclosure? Empirical evidence on how employee postings on social media relate to future corporate disclosures. Accounting, Organizations and Society, 68-69, 88-108. https://doi.org/10.1016/j.aos.2018.04.004

Healy, P. M., \& Palepu, K. G. (2001). Information asymmetry, corporate disclosure, and the capital markets: A review of the empirical disclosure literature. Journal of Accounting and Economics, 31(1-3), 405-440. https://doi.org10.1016/S01654101(01)00018-0

Jones, D. (2011, September 11). CEO pushes Reg FD limits on Twitter. IR Web Report. http://irwebreport.com/20110915/ceo-pushes-reg-fd-limits-on-twitter/

Leary, M. R., \& Kowalski, R. M. (1990). Impression management: A literature review and two-component model. Psychological Bulletin, 107(1), 34-47. https://doi.org/ 10.1037/0033-2909.107.1.34

Masulis, R. W., Wang, C., \& Xie, F. (2012). Globalizing the boardroom-The effects of foreign directors on corporate governance and firm performance. Journal of Accounting and Economics, 53(3), 527-554. https://doi.org/10.1016/j.jacceco. 2011.12.003

Masulis, R. W., Wang, C., \& Xie, F. E. I. (2007). Corporate governance and acquirer returns. The Journal of Finance, 62(4), 1851-1889. https://doi.org/10.1111/j.15406261.2007.01259.x

Menon, R. G. V., Sigurdsson, V., Larsen, N. M., Fagerstrøm, A., Sørensen, H., Marteinsdottir, H. G., \& Foxall, G. R. (2019). How to grow brand post engagement on Facebook and Twitter for airlines?. An empirical investigation of design and content factors. Journal of Air Transport Management, 79, 101678, 1-9. https://doi.org/10.1016/j.jairtraman.2019.05.002

Merkl-Davies, D. M., \& Brennan, N. M. (2011). A conceptual framework of impression management: New insights from psychology, sociology and critical perspectives. Accounting and Business Research, 41(5), 415-437. https://doi.org/10.1080/ 00014788.2011.574222

Modigliani, F., \& Miller, M. H. (1958). The cost of capital, corporation finance and the theory of investment. The American Economic Review, 48(3), 261-297.

$\mathrm{Ng}, \mathrm{C}$. (2013). An exploratory study of metrics used in measuring the impacts of utilizing social networking services on business performance. In Encyclopedia of information science and technology (3 ed.). Information Science Reference. 
Paniagua, J., \& Sapena, J. (2014). Business performance and social media: Love or hate? Business Horizons, 57(6), 719-728. https://doi.org/10.1016/j.bushor.2014. 07.005

Parhankangas, A., \& Ehrlich, M. (2014). How entrepreneurs seduce business angels: An impression management approach. Journal of Business Venturing, 29(4), 543564. https://doi.org/10.1016/j.jbusvent.2013.08.001

Prakash, P., \& Rappaport, A. (1977). Information inductance and its significance for accounting. Accounting, Organizations and Society, 2(1), 29-38. https://doi.org/ 10.1016/0361-3682(77)90005-8

Punel, A., \& Ermagun, A. (2018). Using Twitter network to detect market segments in the airline industry. Journal of Air Transport Management, 73, 67-76. https://doi.org/10.1016/j.jairtraman.2018.08.004

Ramsaran-Fowdar, R., \& Fowdar, S. (2013). The implications of Facebook marketing for organizations. Contemporary Management Research, 9(1), 73-84. https://doi.org/10.7903/cmr.9710

Schlenker, B. R. (1980). Impression management. The self-concept, social identity and interpersonal relations, CA: Brooks/Cole.

Schniederjans, D., Cao, E. S., \& Schniederjans, M. (2013). Enhancing financial performance with social media: An impression management perspective. Decision Support Systems, 55(4), 911-918. https://doi.org/10.1016/j.dss.2012.12.027

She, C. \& Michelon, G. (2019). Managing stakeholder perceptions: Organized hypocrisy in CSR disclosures on Facebook. Critical Perspectives on Accounting, 61, 54-76. https://doi.org/10.1016/j.cpa.2018.09.004

Stein, L. C. D. \& Zhao, H. (2019). Independent executive directors: How distraction affects their advisory and monitoring roles. Journal of Corporate Finance, 56, 199-223. https://doi.org/10.1016/j.jcorpfin.2019.02.003

Vafeas, N. (1999). Board meeting frequency and firm performance. Journal of Financial Economics, 53(1), 113-142. https://doi.org/10.1016/S0304-405X(99) 00018-5

Withers, M. C., Hillman, A. J. \& Cannella, A. A. (2012). A multidisciplinary review of the director selection literature. Journal of Management, 38(1), 243-277. https://doi.org/10.1177/0149206311428671

Yan, G., Watanabe, N. M., Shapiro, S. L., Naraine, M. L., \& Hull, K. (2019). Unfolding the Twitter scene of the 2017 UEFA champions league final: Social media networks and power dynamics. European Sport Management Quarterly, 19(4), 419-436. https://doi.org/10.1080/16184742.2018.1517272 
Yu, Y., Duan, W., \& Cao, Q. (2013). The impact of social and conventional media on firm equity value: A sentiment analysis approach. Decision Support Systems, 55(4), 919-926. https://doi.org/10.1016/j.dss.2012.12.028

Zhang, J. (2015). Voluntary information disclosure on social media. Decision Support Systems, 73, 28-36. https://doi.org/10.1016/j.dss.2015.02.018

Dr. Nivo Ravaonorohanta (Corresponding author) has a $\mathrm{PhD}$ in Accounting and currently works at University of Sherbrooke. Her primary research interests are in the fields of corporate governance, the quality of financial and non-financial information disclosures, and the links between corporate disclosures and performance. She pays particular attention to discretionary narrative disclosures, examines if those are used for impression management rather than incremental information purposes, and assesses its relevance to stakeholders. She has developed a high degree of expertise in mergers and acquisitions.

Dr. Michel Sayumwe holds a Ph.D. in accounting from HEC Montréal. He is an Associate Professor at the Department of Accounting Studies at the University of Quebec at Montreal. His research interests relate primarily to the quality of international accounting standardization by making the link with the governance of listed companies. In particular, it analyzes the theoretical aspects linked to business combinations and political connections. Finally, in the context of economic globalization, he studies questions related to the integration of foreign accounting professionals in another country with a culture different from that of their country of origin. 